\title{
Analysis of Emotional Intelligence and Health Perception of Abroad Students on an Island During the Quarantine
}

\author{
Turkmen Tore $^{1}$, Ceren Karaatmaca ${ }^{2}$, Tutku Yurdakul ${ }^{3}$ Semra Erbas $^{4}$ \\ 1,2,3,4 University of Kyrenia, North Cyprus
}

\begin{abstract}
.
Exceptional situations such as quarantine, curfew and closure imposed due to the epidemic may affect the emotional and behavioral situation of individuals. Even if the conditions caused by the pandemic are interpreted as similar or the same stress factors, this situation leads to different psychological effects in individuals. The changes that the pandemic brings to daily life and their associated effects may be associated with individuals' thoughts and emotional abilities on health. The basic beliefs and schematic structures underlying health cognitions allow individuals to perceive, interpret and live the world as they are inclined. Emotional Intelligence (EQ), can be interpreted briefly as one's recognition of one's own feelings, understanding the feelings of others and managing their own feelings. In this respect, the fact that the person notices change in their emotions with their experiences also causes them to understand and reorient behavioral reactions. Increased social awareness and social skills with emotional intelligence, when working in a supportive way, cause individuals to react more functionally to stressful events and are likely to engage in supportive behaviors towards their environment. In this respect, Emotional Intelligence (EQ) plays an important role both in developing functional health cognitions and for the ability to better deal with health problems. In this research, it is aimed to determine the relationship between emotional intelligence and health cognitions as well as the sub-dimensions of health cognitions, and communication with the families of the students living away from home in quarantine in an island country such as Cyprus. This research is a quantitative and illustrative study designed according to the relational scanning model. The sample consists of 122 students. As data collection tools, firstly demographic information including the frequency of communication with the family in a week and the effects of corona virus on daily life are used. As the second data collection tool, the Schutte Emotional Intelligence Test Main Form is used. The third data collection tool is the Health Cognitions scale prepared by Heather D. Hadjistavropoulos and her colleagues (2012). For analysis of data as SPSS descriptive statistics, Pearson correlation test for the existence of linear relationship between subjects and multinomial regression technique are used for factor interactions. In the findings section of the research, data examining the relationship between emotional intelligence and health cognitions are analyzed with descriptive findings about the effect of COVID-19 outbreak on daily life of students who are studying away from their family on the island. When looking at the impact of the COVID-19 outbreak on daily life, it is seen that it is "noticeably" is the highest comment at $42.6 \%$. Between the health cognition scale and the emotional
\end{abstract}




\section{3rd International Academic Conference on Research in SOCIAL SCIENCES \\ 10- 12 June, 2021 \\ Berlin, Germany}

intelligence scale, Pearson correlation analysis showed a negative, inversely significant correlation. $(r=-0.186$ and $\mathrm{p}=0.040 \mathrm{p}<0,05)$. Accordingly, when people's emotional intelligence increases, their score on the health cognition scale, i.e., their health anxiety scores, decreases. When we looked at the relationship between emotional intelligence and health cognition subgroups, 3 different relationships were identified. A strong association was found between having difficulty coping with disease and thinking the probability of disease was high $(\mathrm{p}=0.023)$ and thinking that the disease was frightening, and the probability of disease was high $(\mathrm{p}=0.000)$. At the same time, an association is found between emotional intelligence and thinking that the disease is frightening $(p=0.042)$. In addition, the inadequacy of medical services $(p=0.04)$ and difficulty in dealing with the disease $(\mathrm{p}=0.034)$ dimensions were determined as factors affecting the frequency of communication with the family when multinomial regression was used to determine the factors affecting the frequency of communication.

Keywords: EQ; Health Cognition; Quarantine; Family Communication; Multinominal Regression

\section{Introduction}

Changes in social, family, economic and health issues have caused psychological changes in individuals, and various factors have increased the severity of the worldwide coronavirus disease (COVID-19) pandemic situation (WHO, 2020). Exceptional circumstances such as quarantine, curfew and closure, which were implemented due to the COVID-19 pandemic, have affected the emotional and behavioral state of individuals. The situation carries predictable evidence for the long-term effects on mental health. Even if the conditions caused by the pandemic could be interpreted as a similar stress factor, the situation may cause different psychological effects due to individual differences (Pulvirenti et al., 2020; Bethell et al., 2021; $\mathrm{Wu}$ et al., 2021). Therefore, to examine the cognitive factors that could be associated with individuals being affected by this pandemic could be subject to research. The changes and the effects in daily life that is associated by the pandemic may be related to the individuals' cognition about health and their emotional skills (Li et al., 2020; Bermejo-Martins et al., 2021). In this respect, it can be considered meaningful to examine health cognition and Emotional Intelligence (EQ).

\subsection{Health Cognition}

Cognitive structures can often affect the perception and the attention processes. And among these cognitive structures, health cognition affects the general perception, interpretation and sensations of the individual (Conner et al., 2013). The basic beliefs and schematic structures underlying health cognition enable individuals to perceive, interpret and live the world as they are inclined. In this respect, the schematic structure, which also forms the basis of health cognitions, provides a self-affirming prophetic life. Self-affirming prophecy may cause 


\section{3rd International Academic Conference on Research in SOCIAL SCIENCES \\ 10- 12 June, 2021 \\ Berlin, Germany}

individuals with a strong schematic structure that they will get sick to interpret even the minor illness symptoms (Hadjistavropoulos et al., 2011; Leahy, 2019). When examined in this respect, in possible individual and global health crises, health cognition may affect the behaviors of individuals (Xin et al., 2020; Asmundson \& Taylor, 2020).

Like other cognitive tendencies, health cognition includes individuals' safety-seeking behaviors and associated anxiety in health domains (Hadjistavropoulos et al., 2011). Moreover, negative health cognitions pose a risk factor for individuals to experience mental health problems such as stress, anxiety, psychosis, and depression (Cowan et al., 2018; Yilmaz \& Dirik, 2018), and dysfunctional health cognitions can reduce physical activity and cause worsening of physical health (Cowan et al., 2018; Yilmaz \& Dirik, 2018). de Jersey et al., 2017; Walsh \& Simpson, 2020). Similarly, studies investigating the psychological mechanisms of accepting misinformation and susceptibility to conspiracy theories suggest that this could be due to cognitive tendencies. That means, individuals with dysfunctional health cognitions could depend on news sources, sensations, and conspiracy theories to validate these cognitions (Lazarević et al., 2021). Physical activity (de-Mateo-Silleras et al., 2018), increase in education level (Conner et al., 2013), family (Alves et al., 2020) and friendship relations play a positive and important role in developing functional health cognition (Sharifian et al., 2020).

\subsection{Health Cognition, Covid-19 and Quarantine}

At this point it has been reported that individuals who display a negative attitude towards COVID-19 have negative health cognition that is having behaviors that will adversely affect their health, not paying attention to scientific warnings (Lazarević et al., 2021). Similarly, as negative health cognitions increase, belief in conspiracy theories against COVID-19 increases (Leibovitz et al., 2021). The changes brought about by the pandemic suggest that the quality of life in individuals with mental illness decreases significantly with the increase in negative health cognition (Karantonis et al., 2021). Another important issue is the situation of individuals quarantined due to COVID-19. Studies have shown that dysfunctional cognitive structures increase the risk of mental illness in individuals in quarantine (Xin et al., 2020; Fiorenzato et al., 2021) and cause anxiety, depression, trauma and stress (de Lima, 2020; El Keshky, Basyouni and Al Sabban, 2020).

\subsection{Emotional intelligence}

EQ can be interpreted briefly as recognizing one's own emotions, understanding others' emotions and managing their own emotions (Goleman, 2020). In this respect, the perception of changes in one's emotions also causes them to understand and re-direct behavioral responses based on emotion (Parker et al., 2021). Having a high EQ does not mean that individuals will not feel stress or anxiety about life issues, but it is the awareness of the person's condition and emotions that is directing towards more functional rather than exaggerated or dysfunctional reactions. Moreover, when emotional intelligence and increased social awareness and social skills work in a supportive manner, it is possible for individuals to react more functionally to stressful events and to behave in support of their environment (Mayer, Caruso, \& Salovey, 2016). Among the factors for high EQ, it has been reported that there are reasons such as good 


\section{3rd International Academic Conference on Research in SOCIAL SCIENCES \\ 10- 12 June, 2021 \\ Berlin, Germany}

relations with the family, high cognitive intelligence and the development of good coping mechanisms (Drigas \& Papoutsi, 2020; Sánchez-Núñez et al., 2020; Jing et al., 2021). EQ is also reported to have effects on problem solving skills and social resilience (Kusché et al., 2020). It has been found that individuals with high EQ are less affected in social violence and stress events (Nyarko et al., 2020). That is, EQ is known to act as a kind of 'stress buffer' and people with higher EQ levels both feel more social support and are more flexible and able to cope better with acute stress (Malouff, Schutte, \& Thorsteinsson, 2013; Lea et al., 2019). In this respect, it can be said that Emotional Intelligence plays an important role both in developing functional health cognitions and in coping with health problems (Ke \& Barlas, 2018).

\subsection{Emotional Intelligence and Covid 19}

It has been revealed that emotional intelligence development programs play an important role in adapting to the changes and preventing burnout that come with COVID-19 (MorenoFernandez et al., 2020). Social interaction positively affects mental health (Bethell et al., 2021) and a lower intensity of fear, anxiety and sadness associated with COVID-19 in individuals with high Emotional Intelligence (Moroń and Biolik-Moroń, 2021) having better coping mechanisms and less stress (Bermejo-Martins et al., 2021). It has been found that individuals experiencing anxiety communicate with their families more and feel the need for social support (Hwang et al., 2020). EQ improves functional coping mechanisms with problems and stress also standing out as a structure that protects the individual in a wide variety of factors caused by COVID-19 (Prentice et al., 2020; Jing et al., 2021).

\subsection{Being on the Island}

The lack of road connections from island countries to continental countries and travel restrictions caused by COVID-19 make it difficult for individuals to return to their countries. Students who are away from both their families and their countries are subject to quarantine and closure restrictions in an island country where they study, which can affect their mental state. (King et al., 2020; Kamberi et al., 2020; Chen et al., 2020; Collins, 2021). It has been reported that students who receive education away from their home cannot return to their homes due to travel restrictions after the COVID-19 pandemic, and their being away from their family and social environment causes them to develop mental illnesses (King et al., 2020; Wathelet et al., 2020; Chen et al., 2020; Collins, 2021). In this respect, it would be meaningful to analyze emotional intelligence and health perception of abroad students on an island during the quarantine.

In the light of all the above information, this study aims to determine the relationship between emotional intelligence and health cognition, by investigating the health cognition subdimensions, emotional intelligence, and communication profiles with the family within the 


\section{3rd International Academic Conference on Research in SOCIAL SCIENCES \\ 10- 12 June, 2021 \\ Berlin, Germany}

scope of the students living away from home in quarantine in an island country such as Cyprus. For this purpose, the following sub-problems have been created.

1. What are the opinions of students, living in quarantine on the island far from their families, about how much the corona virus outbreak affects your daily life?

2. Is there a relationship between health cognitions and emotional intelligence? What is the relational order of emotional intelligence and health cognition which have subdimensions as inadequacy of medical services, , difficulty in coping with the disease, fear of illness, and the possibility of illness?

3. How often do students living in quarantine on the island away from their families communicate with their families? What are the factors that affect the frequency of contacting the family?

\section{Method}

This section details the design used in the study, participants, data collection tools, summary of the process performed and how the data is analyzed.

\subsection{Design}

This research is a holistic study designed according to the relational scanning model. In the scanning models; research approaches to describe a past or current situation as it exists. The event, individual or object subject to the research is tried to be defined in its own conditions. Scanning models are arrangements made on the entire universe or a group. Samples are taken order to reach a general judgment about the universe (Karasar, 2012). The relational scanning model used in this study or the scanning approach aims to determine the presence of change together between two and more variables. In the relational scanning model, it is tried to determine whether the variables have changed together; and if there is a change, how this happens (Creswell, 2007).

\subsection{Participants}

The universe of the study is made up of students who are in quarantine away from their families and study at universities in Northern Cyprus which is an island country, in between March 2020 and May 2020. The sample study of the research is created by unlearned sampling method. The simple non-selective sampling method is applied as two steps. Accordingly, higher education institutions in Northern Cyprus were first listed. This list covers 14 Universities of Northern Cyprus in the 2019 University manual (MFA,2019). In the first stage, 6 universities were designated as unselected. As a selection criterion, it stands out for the student to take online lessons in quarantine by being physically present on the island away from his or her family. The sample is composed of a total of 122 students selected according to 


\section{3rd International Academic Conference on Research in SOCIAL SCIENCES \\ 10- 12 June, 2021 \\ Berlin, Germany}

these defined methods. Demographic information of the participants is included in Tab. 1 and as seen, $39 \%$ of the participants were male and $61 \%$ female ; with age ranges $45.9 \%$ is $18-20$ years old, $43.5 \%$ is $21-23$ years old , $9 \%$ of respondents are 24-26 years old and only $1.6 \%$ are 27 years of age or older. The departments that the participating students study are ,psychology 39.3 ,nursing $17.2 \%$, medicine $9.8 \%$,education $9.0 \%$,other health sciences 7.0 .. $4 \%$, architecture $4.1 \%$, engineering $4.1 \%$, finance related $4.1 \%$, transportation related $2.5 \%$ and law $2.5 \%$. When looking at the places where the participants stayed while on the island, it is seen that dorm is $13.1 \%$, flat in apartment is $63.1 \%$, house is $21.3 \%$ and $2.4 \%$ is the other. For exercising at home, $52.5 \%$ do not have an exercise routine and $47.5 \%$ have regular exercise. When respondents were asked if they had their own vehicles while living on the island, $51.6 \%$ said they had vehicles and $48.4 \%$ said they did not. 
Table 1: Sociodemographic features of participants

\begin{tabular}{|c|c|c|c|}
\hline Sociodemographic Features & & $\begin{array}{l}\text { Number } \\
\text { (n) } \%\end{array}$ & $\%$ \\
\hline \multirow[t]{2}{*}{ Gender } & male & 47 & $39.0 \%$ \\
\hline & Female & 75 & $61.0 \%$ \\
\hline \multirow[t]{4}{*}{ Age } & $18-20$ & 56 & $45.9 \%$ \\
\hline & $21-23$ & 53 & $43.5 \%$ \\
\hline & $24-26$ & 11 & $9 \%$ \\
\hline & 27 and up & 2 & $1.6 \%$ \\
\hline \multirow[t]{10}{*}{ Department } & Psychology & 48 & $39.3 \%$ \\
\hline & Nursing & 21 & $17.2 \%$ \\
\hline & Medicine & 12 & $9.8 \%$ \\
\hline & Education & 11 & $9.0 \%$ \\
\hline & Other Health Sciences & 9 & $7.4 \%$ \\
\hline & Architecture & 5 & $4.1 \%$ \\
\hline & Engineering & 5 & $4.1 \%$ \\
\hline & Finance & 5 & $4.1 \%$ \\
\hline & Transportation & 3 & $2.5 \%$ \\
\hline & Law & 3 & $2.5 \%$ \\
\hline \multirow[t]{4}{*}{ Stay In } & Dorm & 16 & $13.1 \%$ \\
\hline & Flat in apartment & 77 & $63.1 \%$ \\
\hline & house & 26 & $21.3 \%$ \\
\hline & Other & 3 & $2.4 \%$ \\
\hline \multirow[t]{2}{*}{ Exercise at home } & yes & 64 & $52.5 \%$ \\
\hline & no & 58 & $47.5 \%$ \\
\hline \multirow[t]{2}{*}{ Have a car } & yes & 63 & $51.6 \%$ \\
\hline & no & 59 & $48.4 \%$ \\
\hline Total Participants & & 122 & $100 \%$ \\
\hline
\end{tabular}




\section{3rd International Academic Conference on Research in SOCIAL SCIENCES

\subsection{Data collection tools}

In the research, as the first data collection tool, the questionnaire is used in which students who are quarantined in the island country are asked about their age, gender, exercise routines, the ownership of a car, the frequency of communication within a week with their parents , and whether the corona virus outbreak affects their daily life.

As the second data collection tool, Schutte Emotional Intelligence Test is applied. Schutte Emotional Intelligence Test SEIT-33 is an self-assesment test applied too measure emotional intelligence (Brackett and Mayer,2003). The test reported an internal consistency coefficient of 0.90 in the specified study (Schutte , Malouff, Hall, Haggerty,Cooper and Golden, 1998). The Turkish adaptation of this scale was developed in 2017 (Tatar, Tok, Bender and Saltukoglu,2017). With the aforementioned study, it is aimed to translate the original form 33-point Schutte Emotional Intelligence Test (SDZT-33) into Turkish with a heterogeneous participatory application keeping the appropriate factor structure and the number of substances unchanged. With this study, a research pattern parallel to the psychometric characteristics revealed in the development of SDZT-33 was carried out. As a result, the total score of SDZT33 is -0.63 with the Toronto Alexei Scale as part of the benchmark correlated validity study, It was determined that the Revised 41-point Schutte Emotional Intelligence Scale showed a 0.87; within the scope of distinctive validity, the 5 Factor Personality Inventory Short Form showed a correlation coefficient of 0.48 with clarity to development from factors, -0.28 with emotional balance, 0.39 with self-control/responsibility, 0.16 with softness and 0.11 with extroversion. The two separate retest validation coefficients applied after 15 days and 30 days of the test were also found to be 0.81 and 0.78 respectively. It was observed that the test showed a limitingly acceptable one-dimensional factor structure according to the results of the validating factor analysis. The internal consistency coefficient of the test was found to be 0.86 . As a result, it was observed that the values obtained from the form translated into Turkish were quite similar to the values revealed in the study of developing SDZT-33. Therefore, it is appropriate to use this scale in the current study.

As the third data collection tool, the Health Cognitions scale is used. The aforementioned health cognition scale is the original form created by Heather D. Hadjistavropoulos and his friends (2012). Scale is prepared in likert type (I don't agree at all 1, I don't agree much 2, I'm undecided 3, I agree a little 4, I totally agree 5). Scale have 4 sub-factors which are the inadequacy of medical services $(15,7,18,11$ questions) difficulty in dealing with the disease $(10,2,4,19,9,20,6,16$ questions $)$, the fear of the disease $(1,17,14,13$ questions), the probability of disease (8.12.5.3 questions). The validity reliability study, which was carried out by translating the health cognition scale into Turkish, was carried out in 2019 (Altay \& Yüksel, 2019). In this research, validity-reliability studies were carried out in the Turkey sample of the Health Cognitions Scale developed by the original form (Hadjistavropoulos et al, 2012). The original English form of the scale consists of 20 questions and has a 4-factor structure of type 5 Likert. The translation group of the scale was first translated into Turkish by 5 academicians who speak very good English, and then translated back into English in order to avoid any semantic disorders. In order to avoid semantic confusion, the necessary controls were made in terms of spelling and grammar, and then the Turkish form became ready for the first 


\section{3rd International Academic Conference on Research in SOCIAL SCIENCES \\ 10- 12 June, 2021 \\ Berlin, Germany}

applications. It was completed with 500 students, 356 of whom were women and 114 of whom were men. Cronbach's Alpha Internal Consistency Reliability coefficients were calculated to test the reliability of the Health Cognition Scale. As a result of the validating factor analyses, cronbach's Alpha internal coefficient of consistency calculated for the entire Health Cognition Scale was calculated as 0.821 . According to the results of the research, it was concluded that the Health Cognitions Scale is a valid and reliable tool. For these reasons, it is appropriate to use this scale as the third data collection technique in the current study.

\subsection{Process}

The questionnaire mentioned, Schutte Emotional Intelligence Test SDZT-33 original form and health cognition scale were applied online to all participants due to their quarantine. As detailed in the sample section, the participants are students studying online in the period March - May 2020 on the island of Cyprus in quarantine away from their family.

\subsection{Data analysis}

By encoding the data obtained from the scales applied to the participants in the study is installed on the computer. Statistical Program for Social Sciences (SPSS) is used for statistical analysis of data. Descriptive statisticsare given in frequency and percentage. The existence of linear relationship between variables is evaluated by Pearson correlation test, while multinomial regression technique is used for interactions. Multinomial regression is a classification method that generalizes logistic regression to multiclass problems like more than two possible discrete outcomes. That is, it is a model that is used to predict the probabilities of the different possible outcomes of a categorically distributed dependent variable, given a set of independent variables(Greene,2012). In addition, $p<0.05$ is accepted for statistical importance in research data analysis.

\section{Results}

In this part of the research, the findings of the students who are educated away from their family on the island in quarantine, the descriptive findings about the daily life of the COVID-19 outbreak and the relationship between emotional intelligence and health cognitions are included.

\subsection{The impact of the COVID-19 outbreak on daily life}

In this section, students living in quarantine on the island away from the island have a view on how the COVID-19 outbreak affects your daily life. Tab. 2 is based on the participant's discourses, according to this, the likert type of the participants' responses to the effect intensity is not at all (1), very little(2), undecided (3), significantly (4) and too much (5) in the longitude responses (4) $42.6 \%$ with the highest percentage, then too much (5) $37.7 \%$, very little (2) $11.5 \%$, undecided (3) $7.4 \%$, and only 1 student who responded that was not affected at all. 


\section{3rd International Academic Conference on Research in SOCIAL SCIENCES \\ 10- 12 June, 2021 \\ Berlin, Germany}

Table 2: Corona virus outbreak effects on daily life

How much has the corona virus outbreak affected your daily life?

\begin{tabular}{|ll|r|r|r|r|}
\hline & & & & \multicolumn{2}{|c|}{$\begin{array}{c}\text { Cumulative } \\
\text { Percent }\end{array}$} \\
\hline Valid No & Frequency & Percent & Valid Percent &, 8 \\
& 1 &, 8 &, 8 & 12,3 \\
& very little & 14 & 11,5 & 11,5 & 19,7 \\
unstable & 9 & 7,4 & 7,4 & 62,3 \\
markedly & 52 & 42,6 & 42,6 & 100,0 \\
too much & 46 & 37,7 & 37,7 & \\
Total & 122 & 100,0 & 100,0 & \\
\hline
\end{tabular}

\subsection{Health Perception and Emotional Intelligence}

In this section,the health perception and emotional intellegence is measured of the students living in quarantine on the island away from their countries. Tab. 3 is based on the correlation in this respect.

Table 3 : Health Perception and Emotional Intelligence relations

\begin{tabular}{|ll|r|r|}
\hline \multicolumn{2}{|c|}{ Correlations } & health metered & emotional meter \\
\hline Health Perception & Pearson Correlation & 1 &,$- 186^{*}$ \\
& Sig. (2-tailed) & &, $\mathbf{0 4 0}$ \\
& $\mathrm{N}$ & 122 & 122 \\
\hline Emotional Inteleyoung & Pearson Correlation &,$- 186^{*}$ & 1 \\
& Sig. (2-tailed) &, 040 & 122 \\
& $\mathrm{~N}$ & 122 & \\
\end{tabular}

*. Correlation is significant at the 0.05 level (2-tailed).

Pearson Correlation analysis was performed to see if there was a significant correlation between the health cognition scale and the emotional intelligence measure. As a result of pearson correlation analysis, a negative, inversely significant correlation was $\operatorname{detected}(\mathrm{r}=$ 0.186 and $\mathrm{p}=0.040 \mathrm{p} \leq 0.05$ ). Accordingly, when people's emotional intelligence rises, their score on the health cognition scale, i.e. their health anxiety scores, decreases.

Inadequacy of emotional intelligence and medical services, difficulty coping with illness, fear of illness and possibility of illness are also given in this respect. As all these variables are within the measure for health perception. That is emotional intelligence and health cognition 


\section{3rd International Academic Conference on Research in SOCIAL SCIENCES \\ 10- 12 June, 2021 \\ Berlin, Germany}

were looked at in relation to subgroups. As detailed in the method section in this study, the mentioned subgroups are "to think that the services of the medical are inadequate", "to have difficulty in dealing with disease"," to think that the disease is frightening" and "to think that the probability of getting disease is high". As a result of the analysis carried out on the concepts mentioned, 3 different relationships were determined. A strong association was found between the subgroups, especially those who had difficulty coping with the disease and thought the likelihood of the disease was high $(\mathrm{p}=0.023)$ and the thought that the disease was frightening and the probability of disease $(\mathrm{p}=0.000)$ was high. At the same time, an association between emotional intelligence and thinking that the disease is frightening $(\mathrm{p}=0.042)$ has been identified as a response to the research question of the current research. Again $\mathrm{p}$ is considered in all analyses as $\mathrm{p}<0,05$. These details are presented in Tab. 4. 
Table 4: Health Perception Sub-groups and Emotional Intelligence relations

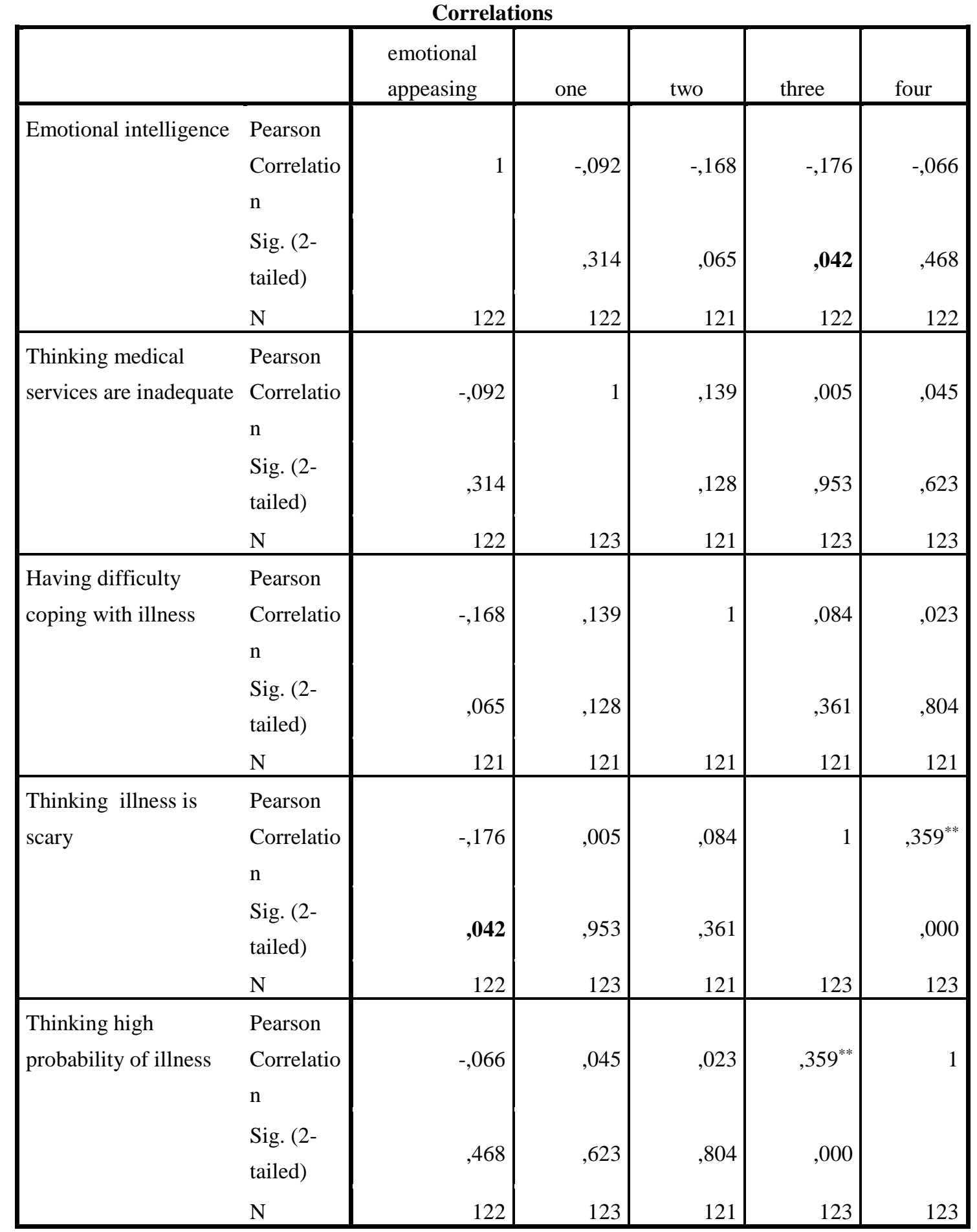

**. Correlation is significant at the 0.01 level (2-tailed). 


\section{3rd International Academic Conference on Research in SOCIAL SCIENCES \\ 10- 12 June, 2021 \\ Berlin, Germany}

\subsection{Factors affecting the communication of students away from the family in quarantine}

In this section, there are descriptive findings about how often students who live in quarantine on the island away from the island communicate with their families and what factors are effective in this communication. In the analysis, multinomial regression, which is also mentioned in the method section, is used.

First of all, the frequency of communication with the family is examined. As stated in Tab. $5,65.6 \%$ of students say they always communicate with their parents, while $18.9 \%$ say they have never had contact, $12.3 \%$ are intermediate, $2.5 \%$ are fewer and only one student says they have never had contact.

Table 5 :. Family Contact Frequency

\begin{tabular}{|ll|r|r|}
\hline \multicolumn{4}{c}{ Case Processing Summary } \\
\hline & & $\mathrm{N}$ & $\begin{array}{c}\text { Marginal } \\
\text { Percentage }\end{array}$ \\
\hline How often do you contact & Never & 1 & $0,8 \%$ \\
your family? & Few & 3 & $2,5 \%$ \\
& Middle & 15 & $12,3 \%$ \\
& A lot & 23 & $18,9 \%$ \\
& All the time & 80 & $65,6 \%$ \\
Valid & & 122 & $100,0 \%$ \\
Missing & & 0 & \\
Total & & 122 & \\
Subpopulation & & $117^{\mathrm{a}}$ \\
\hline
\end{tabular}

A. The dependent variable has only one value observed in 117 (100.0\%) subpopulations.

Then, the model fitting is first performed to check whether multinomial regression can be used to advance the research on what factors are effective in this communication. As shown in Tab. 6 , Sig.,013 is found and $\mathrm{p} \leq 0.05$, the model looks appropriate. 


\section{3rd International Academic Conference on Research in SOCIAL SCIENCES \\ 10- 12 June, 2021 \\ Berlin, Germany}

Table 6 . Model Fit info for Multinominal Regression

\begin{tabular}{|l|r|r|r|r|}
\hline \multirow{2}{*}{} & $\begin{array}{c}\text { Model Fitting } \\
\text { Criteria }\end{array}$ & \multicolumn{3}{|c|}{ Likelihood Ratio Tests } \\
\cline { 2 - 5 } & $\begin{array}{c}\text { Model Fitting Information } \\
\text { Likelihood }\end{array}$ & Chi-Square & Df & Sig. \\
Model & 238,991 & & & \\
Intercept Only & 196,931 & 42,060 & & \\
Finale & & & 24 \\
\hline
\end{tabular}

Multinomial regression is then used to detect the factors affecting the frequency of communication. In this context, the frequency of contact with the family and the properties like age, emotional intelligence, inadequacy of medical services, difficulty in dealing with disease , disease scare and probability of disease are investigated. As can be seen in Tab. 7, the inadequacy of the lack of medical supplies $(\mathrm{p}=0.04)$ and difficulty in dealing with the disease $(\mathrm{p}=0.034)$ were determined as factors that affected the frequency of communication with the family $(\mathrm{p} \leq 0.05)$.

Table 7. Multinomial Regression for factors affecting the frequency of communicating with the family

\begin{tabular}{|c|c|c|c|c|}
\hline \multirow[b]{3}{*}{ Effect } & \multicolumn{3}{|c|}{ Likelihood Ratio Tests } & \\
\hline & $\begin{array}{c}\text { Model Fitting } \\
\text { Criteria }\end{array}$ & \multicolumn{3}{|c|}{ Likelihood Ratio Tests } \\
\hline & Model & Chi-Square & Df & Sig. \\
\hline Intercept & 201,013 & 4,082 & 4 & 395 \\
\hline Age & 197,078 & ,147 & 4 & 997 \\
\hline $\begin{array}{l}\text { Thinking medical services are } \\
\text { inadequate }\end{array}$ & 212,372 & 15,441 & 4 & ,004 \\
\hline $\begin{array}{l}\text { Having difficulty coping with } \\
\text { illness }\end{array}$ & 207,350 & 10,418 & 4 & ,034 \\
\hline Thinking illness is scary & 202,227 & 5,296 & 4 & ,258 \\
\hline $\begin{array}{l}\text { Thinking high probability of } \\
\text { illness }\end{array}$ & 204,385 & 7,454 & 4 & 114 \\
\hline Emotional Intelligence & 201,195 & 4,264 & 4 & ,371 \\
\hline
\end{tabular}

The chi-square statistic is the difference in -2 log-likelihoods between the final model and a reduced model. The reduced model is formed by omitting an effect from the final model. The null hypothesis is that all parameters of that effect are 0 . 


\section{3rd International Academic Conference on Research in SOCIAL SCIENCES \\ 10- 12 June, 2021 \\ Berlin, Germany}

\section{Discussion}

As detailed in the results or findings section, the effects of the quarantine because of corona virus outbreak on daily life, emotional intelligence, health perception with the sub-dimensions as thinking medical services are inadequate, having difficulty coping with illness, thinking that illness is scary, and thinking high probability of illness are analyzed. Additionally, the factors affecting the communication of students living far away from their families during quarantine on an island are discussed according to the findings.

\subsection{The impact of the Corona virus outbreak on daily life}

In the analysis of the responses created according to their own discourses, the students who are away from their families in quarantine often say that the level of impact of the pandemic on daily life is high. In a similar study conducted in Turkey, the change of habits is presented with concrete data by linking some factors with daily life in order to determine the high effect on daily life habits of the Coronavirus outbreak (Akameter, 2021). In this context, it is seen that the frequency of showering increased by $4.1 \%$, the frequency of washing clothes increased by approximately $36 \%$, the frequency of cleaning the house increased by $46 \%$, the consumption of home-prepared products increased and the consumption of "homemade baked goods" increased the most. At the same time, it is reported that the most missed food consumed outside is the "simit", which can be called as "Turkish bagel". Apart from these concrete daily life data samples, there are also studies on fear, exaggerated perception of danger and sensitivity reactions in individuals during the mentioned outbreak (Yildirim et al. 2021).

At this point, the continuation of the pandemic in the world and in Turkey can cause psychological problems that can lead to despair in society (Lee et al.2020). It has been shown in studies that many psychological reactions such as short- and long-term phobias, anxiety disorders, suicide attempts, despair have been observed in the short and long-term following SARS and MERS outbreaks (Colorado, 2017; Kim and Song 2017). Likewise, the number of studies on the various psychological consequences of COVID-19 is increasing day by day.

Especially when we look at the effects of other virus outbreaks on daily life, it is seen that similar results are obtained with the current study. A study on SARS in Hong Kong on effects and social pressures focuses on behavioral constraints and psychological effects, which are indirect costs of the virus outbreaks (Forster and Ya Tang, 2005). Hong Kongers describes the way in which the virus changed behavior aprevailing sense of helplessness among the population, especially among those whose income or jobs are being affected. And it is also note that the psychological impact of pandemics was due to the rapid spread of misinformation combined with a lack of reliable medical information about the symptoms, mode of transmission, morbidity, and vulnerable populations. Similarly, in similar research, participants mention that the pandemic affects their daily lives. The lack of road connections from island countries to continental countries and travel restrictions due to COVID-19 make it difficult for individuals to return to their countries. This study is included in this study to take an in-depth look at the other possible variables related to impact, such as health cognition, emotional 


\section{3rd International Academic Conference on Research in SOCIAL SCIENCES \\ 10- 12 June, 2021 \\ Berlin, Germany}

intelligence, frequency of communication with the family, as well as factors such as. In the results, the participants' high-level declarations that they were affected in their daily lives can shed light on different aspects.

\subsection{Health Perception and Emotional Intelligence}

The science of psychology contains many theories that explain the formation of emotions. According to the "James - Lange Theory" (James, 1884), which provides the first explanations on this subject, environmental stimuli cause physiological changes in the body, and these physiological changes cause emotions. According to the "Cannon - Bard Theory" (Cannon,1931) the meanings attributed by individuals to these stimuli together with external stimuli constitute the beginning of the formation of emotions and the meanings attributed to stimuli reveal physiological and behavioral responses accompanying the emotions that are being formed. With these past theories in hand style today there is currently no scientific consensus on a definition. But emotions can be summarized as biological states associated with all of the nerve systems brought in by neurophysiological changes variously associated with thoughts, feelings, behavioral responses, and a degree of pleasure or displeasure. Emotions are often intertwined with mood, temperament, personality, disposition, creativity, and motivation (Cabanac, 2002).

As mentioned above, although there is no complete consensus on the definition of emotion (Atkinson, R.L., Atkinson, Smith, Bem, and Nolen-Hoeksema, 1999), studies on its functions (Eysenck, 2004) and classification (Akbas, 2006) continue to progress. Based on these studies, it is useful to address the subject of emotional intelligence, which is in essence considered the ability to use emotions intelligently.

At the point mentioned, emotional intelligence, which is considered as a potential sign of the emotional, personal and social dimensions of intelligence, has also been defined in various ways by different theorists. According to Daniel Goleman (1998), who has done the best-known work on this subject of emotional intelligence, defines people with high EQ as being able to recognize the feelings of themselves and others, to effectively reflect the knowledge and energy of emotions into daily life. Intelligence; reasoning, rational thinking, planning, problem solving, abstract thinking, comprehension of complex ideas, quick learning, trying and learning skills are defined as a general mental capacity (Dokmen, 1989). In the definition of intelligence mentioned, it reflects a broad and deep capacity for the ability to make sense of, to monitor, to draw conclusions and to plan for those around us rather than the high score meaning from a skill test (Goleman, 1998) Theorists who adopt the understanding of emotional intelligence, based on this idea state that to succeed and to live a happy life, intellectual intelligence is not enough alone (Stough, Saklofske, and Parker, 2009).

In dealing with stress, there are two types as problem-oriented coping and emotion-oriented coping. Problem-oriented coping stands out as the individual's use of knowledge and logical analysis to actively eliminate the stressful situations(Goleman,1998). It is seen that the 


\section{3rd International Academic Conference on Research in SOCIAL SCIENCES

basis of problem-oriented coping is to face this goal by directly targeting the source that creates the stress (Dokmen, 1989).. In problem-oriented approaches, individuals try to reduce the effect of stress with similar situations such as receiving advice, developing new skills and , making plans. Research shows that emotional intelligence positively affects coping with problem-oriented stress( Morales et al., 2019).

On the other hand, when looking at the concept of health cognitions, which is another variable in this research, the concept of health cognitions between cognitive structures refers to the influence of the general perception, interpretation and sensation of the individual related to a possible health condition (Conner et al., 2013). The basic beliefs and schematic structures underlying health cognitions enable individuals to perceive, interpret and live the world as they are inclined to do. As can be seen in the findings section, the relationship between emotional intelligence and health cognition subgroups is also examined. The subgroups mentioned are "thinking that medical services are inadequate", "having difficulty coping with the disease", "thinking that the disease is frightening" and "thinking that the probability of disease is high". As given in the findings section, three 3 different relationships were determined as a result of the analyses carried out on the five concepts mentioned. At the point mentioned, a strong relationship was found between having difficulty dealing with the disease and thinking that the probability of the disease was high. On the other hand, another strong relationship stands out as the relationship between thinking that the disease is frightening and the probability of disease is high. The third relationship was found between emotional intelligence and thinking that the disease was frightening. Studies showing an association between being mentally and physically healthy and coping with stress and emotional intelligence are parallel with the current literature. When disease scare is treated as a stress factor, the result of this study is in parallel with the literature. One of the sample studies, Pau and Croucher (2003), found an inverse relationship between emotional intelligence and perceived stress level, and found that participants with low levels of emotional intelligence had high perceived stress levels. These people with low levels of emotional intelligence were also more inadequate in dealing with stress and were subjected to higher levels of stress (Pau and Croucher, 2003, p.1023-1028). Similarly, as a result of the study conducted by Arora and others (2010), it has been found that there are meaningful relationships between emotional intelligence dimensions and coping with stress. In another study, Sarabia, Cobo and others (2017) applied to 92 nurses and nursing assistants and the sample group had significant differences between emotional intelligence before and after work and levels of coping with stress during this time and levels of coping with stress have been observed to improve. As a result of the study, significant relationships of $1 \%$ were found between some sub-dimensions of emotional intelligence and coping with stress (Sarabia Cobo, et al., 2017, p.94-98). Therefore, the results that emerged in our current study actually addressed previous stress studies in a sense in terms of the concept of health cognition, and a reversal relationship was found between thinking that the disease is scary and emotional intelligence. In this context, as emotional intelligence rises, it is thought that the disease is frightening . It is seen that the basis of problem-oriented coping is to face this goal by directly targeting the source that creates the stress. In problem-oriented approaches, individuals try to reduce the effect of 


\section{3rd International Academic Conference on Research in SOCIAL SCIENCES \\ 10- 12 June, 2021 \\ Berlin, Germany}

stress with similar situations such as receiving advice and advice, developing new skills, making plans. Research shows that emotional intelligence positively affects coping with problem-oriented stress.

At the same time, the above definition of emotional intelligence, especially the direction of semantics, monitoring, being able to come out with conclusions and planning, forms the basis of this research, in which it can stand out as an important factor within the scope of health cognitions, especially during the pandemic period. It can be emphasized that especially during the period of the pandemic, when transportation opportunities in the island and off the island are limited. As the results show, when the ability to plan and follow up is associated, emotional intelligence can be explained in this context.

\subsection{Factors affecting the communication of students away from the family in quarantine}

As seen in the results, "the inadequacy of the lack of medical supplies" ( $p=0.04)$ and "difficulty in dealing with the disease" $(\mathrm{p}=0.034)$ were determined as factors that affected the frequency of communication with the family $(p \leq 0.05)$.

Thanks to mutual communication, it is possible to maintain relations. Families who communicate openly, complementably, appropriately with each other and express their feelings/thoughts are healthy families. Open and honest communication established within the family is extremely valuable. Positive communication is about the ability of people in the family to understand themselves and others. (Yavuzer, 2005). In case studies, it was found that the communication skills of individuals have an important and meaningful effect on the point of coping with stress and in stress management (Koçyiğit, 2018). Akbaba (2004) states that people who can produce effective solutions in interpersonal relationships believe that by comparing the current situation with what should be, situations such as stress and anxiety can solve many of the problems they face through their communication skills.

On the other hand, another finding of analysis obtained in the researches is that there is a significant relationship between communication skills and the level of coping with stress. In this respect, it has also been determined that effective communication skills have a positive and meaningful effect on the level of coping with stress of individuals (Koçyiğit, 2018). As the current study found. This can occur as one of the methods of dealing with the stress on health concerns. As a result, since the family is also the "safe base" of the young individual, communication with the family can positively affect their health cognition. 


\section{3rd International Academic Conference on Research in SOCIAL SCIENCES \\ 10- 12 June, 2021 \\ Berlin, Germany}

\section{Conclusion}

The so far chapters of the study examine the relationship between emotional intelligence and health cognitions and include explanations of the impact of COVID-19 outbreak on daily life of students studying away from their families on an island. Discussion also focuses on the frequency of communication with their families reducing the stress that may arise from health cognitions.

At this point, when we first look at the impact of the COVID-19 outbreak, it is seen that most of the participants indicate that the effect is high in their daily lives. In addition, it is analyzed and discussed that when the emotional intelligence of the participants increases, their scores on the health cognition scale, that is, their health anxiety scores decrease. At the same time, it is reported that when you look at the relationship between subgroups of emotional intelligence and health cognition, there is a significant relationship between emotional intelligence and thinking that the disease is frightening. In addition, according to the multinomial regression applied to determine the factors affecting the frequency of communication, it can be said that the frequency of communication with the family increases for participating students who think that medical services are inadequate and have difficulty coping with the disease.

On the other hand, anxiety, like all other emotions, can be defined as a feeling that directs our responses to internal and external stimuli and contains physiological signs (Yavuzer, 2005). If anxiety increases to a level that prevents the flow of daily life, it prevents us from acting appropriately and can break down our coping mechanisms. Although it is quite normal to feel anxiety during periods when life is disconnected from its normal flow, such as Covid-19, denying, trying to suppress, ignoring this anxiety may reduce or, conversely, increase anxiety as in all other emotions. It will be much easier to think carefully about trying to forget anxiety and to be able to think calmly about when it started, what it is associated with, and to get over it. At this point, factors such as emotional intelligence and frequency of communication with the family can also come into play. It is also important to realize that the individual is not the only person who feels anxiety within the given condition and healthy communication can help both in dealing with anxiety and in taking the necessary measures for the cause of anxiety.

The issue of dealing with quarantine due to Covid-19 can also emerge as an important issue at this point. In this context, an important challenge that must be dealt with in general is to stay indoors. However, if it is in an island country, a situation has arisen that cannot be reached by road on top of being confined at home, and there is only a limited number of transportations with only special permits. Also, the fact that the participants are separated from their family is another difficulty point. Maybe the most important thing that makes a prison a punishment is to know that you cannot go out when you want to. Curfews and travel restrictions during the pandemic can give us the feeling that we are in a prison. Knowing that this is a source of stress that arises from the way we think, can also lead a way to remember that we can deal with it by changing the way we think. However, it should be considered that this level of awareness can be reached by having a certain level of emotional intelligence. 


\section{3rd International Academic Conference on Research in SOCIAL SCIENCES \\ 10- 12 June, 2021 \\ Berlin, Germany}

\section{References}

Akametre (May 2021). Akademetre koronavirüs sürecinin günlük yaşama etkisi. Kantitatif Araştırma Raporu [Online]. Available: https://www.akademetre.com/Slider/AkademetreKoronavirus-Surecinin-Gunluk-Yasama-Etkisi.pdf

Akbaba, S. (2004). Psikolojik Sağlı̆̆ı Koruyucu Rehberlik ve Psikolojik Danışma, Ankara: Pegem Yayıncılık.

Akbaş, E. (2006). İstanbul ili Fatih ilçesi ilköğretim okulu öğretmenlerinin duygusal zekâ düzeylerinin belirlenmesi. [Yayınlanmamış Yüksek Lisans Tezi]. Yeditepe Üniversitesi, Sosyal Bilimler Enstitüsü.

Alves, R., Precioso, J., Becoña, E. (2020). Well-being and health perception of university students in Portugal: The influence of parental support and love relationship. Health Psychology Report, vol. 8(2), pp. 145-154. https://doi.org/10.5114/hpr.2020.94723

Atkinson, R. L., Atkinson, R. C., Smith, E. E., Bem, D. J. \& Nolen-Hoeksema, S. (1999).

Psikolojiye giriş. (Çev: Y. Alogan). Ankara: Arkadaş Yayınları.

Brackett M. A., James, W. (1884). What is an emotion? Mind, vol. 9, pp. 185-205.

Brackett, M. A., Mayer, J. D. (2003). Convergent, discriminant, and incremental validity of competing measures of emotional intelligence. Personality and Social Psychology Bulletin, vol. 29(9), pp. 1147-1158. https://doi.org/10.1177/0146167203254596

Cabanac, Michel (2002). "What is emotion?" Behavioural Processes vol. 60(2), pp. 69-83.

Cannon, W. B. (1931). Against the James-Lange and the thalamic theories of emotions. Psychological Review, vol. 38(4), pp. 281-295. https://doi.org/10.1037/h0072957

Chen, J., Li, Y., Wu, A., \& Tong, K. (2020). The overlooked minority: Mental health of International students worldwide under the COVID-19 pandemic and beyond. Asian Journal Of Psychiatry, vol. 54, 102333. https://doi.org/10.1016/j.ajp.2020.102333

Collins, F. E. (2021). Measuring COVID-19-related fear and threat in Australian, Indian, and Nepali university students. Personality And Individual Differences, vol. 175, 110693. https://doi.org/10.1016/j.paid.2021.110693

Colorado, E. E. (2017). A mixed-method study of aid workers in Sierra Leone during the 2014-2015 Ebola epidemic: Exploring psychological distress, trauma, resilience, and coping [Doctoral dissertation]. Chicago, Chicago School of Professional Psychology.

Cowan, H., McAdams, D., Mittal, V. (2018). Core beliefs in healthy youth and youth at ultra high-risk for psychosis: Dimensionality and links to depression, anxiety, and attenuated psychotic symptoms. Development And Psychopathology, vol. 31(1), pp. 379-392.

https://doi.org/10.1017/s0954579417001912 


\section{3rd International Academic Conference on Research in SOCIAL SCIENCES \\ 10- 12 June, 2021 \\ Berlin, Germany}

Creswell, J. W. 2007. Qualitative inquiry and research design: Choosing among five approaches, 2nd ed. Thousand Oaks: Sage.

de-Mateo-Silleras, B., Camina-Martín, M., Cartujo-Redondo, A., Carreño-Enciso, L., de-laCruz-Marcos, S., \& Redondo-del-Río, P. (2018). Health perception according to the lifestyle of university students. Journal Of Community Health, vol. 44(1), pp. 74-80. https://doi.org/10.1007/s10900-018-0555-4

Dokmen, Ü. (1989). The distribution of emotional facial expressions over two dimensions. Ankara University, Journal of the Faculty of Educational Sciences, vol. 22 (1), pp. 303-319.

Eysenck, M.W. (2004). Psychology: An international perspective. New York: USA.

Ferguson, E. (2009). A taxometric analysis of health anxiety. Psychological Medicine, vol. 39, pp. 277-285. https://doi.org/10.1017/S0033291708003322

Fiorenzato, E., Zabberoni, S., Costa, A., \& Cona, G. (2021). Cognitive and mental health changes and their vulnerability factors related to COVID-19 lockdown in Italy. PLOS ONE, vol. 16(1), e0246204. https://doi.org/10.1371/journal.pone.0246204

Forster, C., Tang, Y. (2005). The Role of Online Shopping and Fulfillment in the Hong Kong SARS, Proceedings of the 38th Hawaii International Conference on System Sciences $-2005$.

Goleman, D. (1998). Why is emotional intelligence more important than IQ? (Translated by B. S. Yuksel). (6th Edition), Istanbul: Varlık Yayınları.

Greene, W. H. (2012). Econometric Analysis (Seventh ed.). Boston: Pearson Education. pp. 803-806. ISBN 978-0-273-75356-8.

Hadjistavropoulos, H., Janzen, J., Kehler, M., Leclerc, J., Sharpe, D., \& Bourgault-Fagnou, M. (2011). Core cognitions related to health anxiety in self-reported medical and nonmedical samples. Journal Of Behavioral Medicine, vol. 35(2), pp. 167-178. https://doi.org/10.1007/s10865-011-9339-3

James, W. (1884). What is an emotion? Mind, vol. 9, pp. 185-205.

Kamberi, F., Jaho, J., Mechili, E., Sinaj, E., \& Skendo, H. (2020). Effect of Covid-19 pandemic on mental health among Albanian people residing in the country and abroad Implications for mental care. Archives Of Psychiatric Nursing, vol. 34(6), pp. 507-512. https://doi.org/10.1016/j.apnu.2020.08.003

Karantonis, J., Rossell, S., Berk, M., \& Van Rheenen, T. (2021). The mental health and lifestyle impacts of COVID-19 on bipolar disorder. Journal Of Affective Disorders, vol. 282, pp. 442-447. https://doi.org/10.1016/j.jad.2020.12.186

Karasar, N. (2012). Bilimsel araştırma yöntemi: kavramlar, ilkeler, teknikler. Nobel Yayın Dağıtım.

Ke, T., Barlas, J. (2018). Thinking about feeling: Using trait emotional intelligence in understanding the associations between early maladaptive schemas and coping 


\section{3rd International Academic Conference on Research in SOCIAL SCIENCES \\ 10- 12 June, 2021 \\ Berlin, Germany}

styles. Psychology And Psychotherapy: Theory, Research And Practice, vol. 93(1), pp. 120. https://doi.org/10.1111/papt.12202

Kim, C. W., Song, H. R. (2017). Structural relationships among public's risk characteristics, trust, risk perception and preventive behavioral intention: The case of MERS in Korea.

Crisis and Emergency Management, vol. 13, pp. 85-95.

https://doi.org/10.14251/crisisonomy.2017.13.6.85

King, J., Cabarkapa, S., Leow, F., \& Ng, C. (2020). Addressing international student mental health during COVID-19: an imperative overdue. Australasian Psychiatry, vol. 28(4), pp. 469-469. https://doi.org/10.1177/1039856220926934

Koçyiğit, M., Koçyiğit A., ve Özsoy, E. (2018) Kişilerarası iletişim bağlamında bireylerin iletişim becerileri ile stresle başa çıkma düzeyleriarasındaki ilişkinin incelenmesi: Milli sporcular üzerinde bir araştırma. Türk Spor Bilimleri Dergisi, 1(1), 11-19.

Li, S., Wang, Y., Xue, J., Zhao, N., \& Zhu, T. (2020). The Impact of COVID-19 Epidemic Declaration on Psychological Consequences: A Study on Active Weibo Users. International Journal Of Environmental Research And Public Health, vol. 17(6), 2032. https://doi.org/10.3390/ijerph17062032

Mayer, J., Caruso, D., Salovey, P. (2016). The ability model of emotional intelligence: Principles and updates. Emotion Review, vol. 8(4), pp. 290-300. https://doi.org/10.1177/1754073916639667

Mechanic, D., Volkart, E. H. (1960). Illness behavior and medical diagnoses. Journal of Health and Human Behavior, vol. 1(2), pp. 86-94.

Milman, E., Lee, S., Neimeyer, R., Mathis, A., \& Jobe, M. (2020). Modeling pandemic depression and anxiety: The mediational role of core beliefs and meaning making. Journal Of Affective Disorders Reports, vol. 2, 100023. https://doi.org/10.1016/j.jadr.2020.100023

Ministry of Foreign Affairs. (2019). Universities with Council of Higher Education accreditation. Turkish Republic of Northern Cyprus Ministry of Foreign Affairs. Available: https://istanbul.mfa.gov.ct.tr/egitim-ateseligi/yok-denklikli-universiteler/

Morales-Rodríguez, FM, Pérez-Mármol, JM (2019) The role of anxiety, coping strategies, and emotional intelligence on general perceived self-efficacy in university students. Frontiers in Psychology 10: 1-9. DOI: 10.3389/fpsyg.2019.01689.

Moreno-Fernandez, J., Ochoa, J., Lopez-Aliaga, I., Alferez, M., Gomez-Guzman, M., LopezOrtega, S., \& Diaz-Castro, J. (2020). Lockdown, emotional intelligence, academic engagement and burnout in pharmacy students during the quarantine. Pharmacy, vol. 8(4), pp. 194. https://doi.org/10.3390/pharmacy8040194

Patel, A., Sharma, P. S. V. N., Kumar, P., \& Binu, V. S. (2018). Illness cognitions, anxiety, and depression in men and women undergoing fertility treatments: A dyadic approach. Journal of Human Reproductive Sciences, vol. 11(2), pp. 180-189.

https://doi.org/10.4103/jhrs.JHRS_119_17 


\section{3rd International Academic Conference on Research in SOCIAL SCIENCES \\ 10- 12 June, 2021 \\ Berlin, Germany}

Pearce, E., Launay, J., \& Dunbar, R. (2015). The ice-breaker effect: Singing mediates fast social bonding. Royal Society Open Science, vol. 2(10), 150221.

https://doi.org/10.1098/rsos.150221

Pulvirenti, F., Cinetto, F., Milito, C., Bonanni, L., Pesce, A., \& Leodori, G. et al. (2020). Health-related quality of life in common variable immunodeficiency Italian patients switched to remote assistance during the COVID-19 pandemic. The Journal Of Allergy And Clinical Immunology: In Practice, vol. 8(6), pp. 1894-1899.e2.

https://doi.org/10.1016/j.jaip.2020.04.003

Schultz, D. P., Schultz, S. E. (2007). Modern history of psychology. (Translated by Y. Aslay). Istanbul: Kaknus Yayınları.

Schutte, N. S., Malouff, J. M., Hall, L. E., Haggerty, D. J., Cooper, J. T., Golden, C. J. (1998). Development and validation of a measure of emotional intelligence. Personality and Individual Differences, vol. 25(2), pp. 167-177. https://doi.org/10.1016/S01918869(98)00001-4

Steiner, C. (2009). Emotional literacy with a smart heart. (Trans. Ed: M. Şahin.), Ankara: Bilge Sistem Yayınc1lık.

Stough, C., Saklofske, D. H. ve Parker, D. A. (2009). A brief analysis of 20 years of emotional intelligent: An introduction to assesssing emotional intelligent: Theory, research and aplications. Emotional Intelligent, vol.1, pp. 3-8.

Tatar, A., Tok, S., Tekin Bender, M., Saltukoğlu, G. (2017). Adaptation of the revised Schutte Emotional Intelligence Scale into Turkish and examination of its psychometric properties. Anatolian Journal of Psychiatry, vol. 18(2), pp. 139-146.

Taylor, S. (2004). Understanding and treating health anxiety: A cognitive-behavioral approach. Cognitive and Behavioral Practice, vol. 11(1), pp. 112-123.

Titrek, O. (2010). IQ'dan EQ’ya: Duyguları zekice yönetme. (2. Basım), Ankara: Pegem Akademi Yayıncılık.

Tunal, Özdemir, A. (2008). Preschool teacher candidates' musical competencies and thesis, Abant Izzet Baysal University, Institute of Social Sciences, Bolu.

Wang, X., Hujjaree, K., \& Wang, F. (2020). Mental Health Impacts for International Students During the COVID-19 Pandemic in China. https://doi.org/10.21203/rs.3.rs-49168/v1

Wathelet, M., Duhem, S., Vaiva, G., Baubet, T., Habran, E., \& Veerapa, E. et al. (2020). Factors associated with mental health disorders among university students in France confined during the COVID-19 Pandemic. JAMA Network Open, vol. 3(10), e2025591. https://doi.org/10.1001/jamanetworkopen.2020.25591

World Health Organization. (2020). Coronavirus disease (COVID-19) pandemic. Available: https://www.who.int/emergencies/diseases/novel-coronavirus2019? adgroupsurvey $=\{$ adgroupsurvey $\}$ gclid=Cj0KCQiAj9iBBhCJARIsAE9qRtBD8W5 QhcKcWLL2mq67i8bl2KtZ-EgmiPK1YAiY7VyznNLDE6dXeiEaAhFlEALw_wcB 
Wu, T., Jia, X., Shi, H., Niu, J., Yin, X., Xie, J., \& Wang, X. (2021). Prevalence of mental health problems during the COVID-19 pandemic: A systematic review and metaanalysis. Journal Of Affective Disorders, vol. 281, pp. 91-98. https://doi.org/10.1016/j.jad.2020.11.117

Xin, M., Luo, S., She, R., Yu, Y., Li, L., \& Wang, S. et al. (2020). Negative cognitive and psychological correlates of mandatory quarantine during the initial COVID-19 outbreak in China. American Psychologist, vol. 75(5), pp. 607-617. https://doi.org/10.1037/amp0000692

Yavuzer, H. (2005). Anne-Baba ve Çocuk. (18. Basım), Istanbul : Remzi Kitabevi.

Yıldırım, M., Geçer, E., Akgül, Ö. (2021). The impacts of vulnerability, perceived risk, and fear on preventive behaviours against COVID19. Psychology, Health \& Medicine, vol. 26(1), pp. 35-43.

Y1lmaz, O., Dirik, G. (2018). Examination of the psychometric properties of health cognitions questionnaire (HCQ)'s Turkish version. Nesne Psikoloji Dergisi, vol. 6(13), pp. 337-366. https://doi.org/10.7816/nesne-06-13-05

Y1lmaz, S. (2007). The relationship between emotional intelligence and academic achievement [Unpublished Master's Thesis]. Atatürk University, Institute of Social Sciences, Erzurum. 